\title{
Effect of Germination and Autoclaving of Sprouted Finger Millet and Kidney Beans on Cyanide Content
}

\author{
BERNARD E. CHOVE ${ }^{14 *}$ and PETER R.S. MAMIRO ${ }^{1}$ \\ ${ }^{I}$ Department of Food Science and Technology, Sokoine University of Agriculture, \\ P.O. Box 3006, Morogoro, Tanzania
}

\begin{abstract}
Cyanide contents of locally purchased brown finger millet (Eleusine corocana L. Gaertner) and brown speckled kidney bean seeds (Phaseolus vulgaries var. Rose Coco) were determined using raw, germinated and autoclaved samples. The aim was to establish the extent of cyanide content increase resulting from the germination process and the effectiveness of the autoclaving process on the reduction of cyanide levels in the samples, for safety considerations. Autoclaving was carried out at $121^{\circ} \mathrm{C}$ for 20 minutes. It was found that germination increased the cyanide content by 2.11 to 2.14 fold in finger millet for laboratory processed samples. In the case of kidney beans the increment was 1.76 to 1.77 fold for laboratory samples. The increments for field processed samples were in the same range as those for laboratory samples. Autoclaving reduced the cyanide content to between 61.8 and $65.9 \%$ of the original raw contents for finger millet and between 56.6 to $57.8 \%$ in the case of kidney beans. The corresponding reductions for field samples were also found to be within the same ranges as the laboratory processed samples. It was concluded that autoclaving significantly reduced the cyanide levels in germinated finger millet and kidney beans.
\end{abstract}

Keywords: cyanide, autoclaving, germination, millet, beans, complementary food

\section{Introduction}

Steeping of grains (cereals and legumes) in water followed by germination or sprouting is a common household practice in developing countries including Tanzania (Shayo et al., 1998). Germination reduces the high viscosity and water-binding characteristic of starch based porridges. As soon as the cereal and legume seeds are hydrated, chemical changes occur, which result in partial breakdown of storage components, such as starch and proteins. The starch nature of the un-germinated grains allows these foods to bind so much water yielding a thick porridge. Dilution of the porridge increases bulk and renders the food more difficult for infants to consume in one sitting. The bulkiness of the porridge limits adequate amount of nutrient intake by the infants. Thus germination is mainly used to lower dietary bulk in cereals because it converts significant amounts of starch, which is principally responsible for viscosity in cereal gruels, to sugars and short chain oligosaccharides (Maleshi et al., 1989; Wahed et al., 1994; Onyeka \& Dibia, 2002; Traoré et al., 2004).

In the process of germination of seeds, cyanides are equally mobilized not only to take

\footnotetext{
* Correspondence: Prof. Bernard E. Chove; Email: bchove@ suanet.ac.tz, or bchove06@yahoo.com
}

part in some metabolic processes but also as a protective or defense mechanism agents when the shoot is emerging (Halkier \& Moller, 1989; Jones, 1998). In order to protect their own tissues, plants may physically sequester or localize secondary compounds in specialized vacuoles, plastids, glands, cell walls, or plant part surfaces. The compounds are then released when the plant part is crushed or punctured (Marriott, 2000). These compounds are said to be widely distributed in plants although they occur in trace amounts mainly in the form of cyanogenic glucosides. The glucosides release cyanide when hydrolyzed in the gastro-intestinal tract or when they come into contact with appropriate enzymes such as linamarase (Fennema, 1985).

Glucosides that have been identified in edible plants include amygdalin found in variable amounts in the flowers, leaves, and seeds of the Prunus plants including peaches, plums, apricots, bitter almonds. Other plants include apples and pear seeds, linseeds, bamboo, corn, sweet potatoes, and millet. Dhurrin, which is found in sorghum grass, and other cereals, has been implicated in a number of poisonings in grazing animals (Schneider \& Anderson, 1986). Cassava and certain lima beans contain linamarin, which is another cyanogenic glycoside that has been implicated in a number of cases of acute and chronic cyanide poisoning throughout the world (Drewnowski \& Gomez-Carneros, 2000) 
Cyanide readily and reversibly binds to a number of proteins and enzymes in the body, particularly those with a metallic component. It has a special affinity for iron in its trivalent (ferric) state and is capable of binding to all enzymes and proteins containing iron, including haemoglobin, myoglobin, catalase, and the cytochrome system (Ahmed et al., 1996; Uvere et al., 2000)). Its most significant interaction is its binding to the ferric iron of the mitochondrial cytochrome oxidase system. Cyanide binds to the cytochrome aa3 complex, thus inhibiting oxidative phosphorylation and paralyzing cellular respiration. This results in anaerobic metabolism, increased lactic acid production, reduced ATP stores, and anoxic cell death (Leavesley et al., 2008). The organ systems that are most sensitive to cyanide toxicity are those with the highest oxygen utilization that cannot tolerate hypoxic stress, namely the central nervous system and the myocardium (Muzanila, 1993; Marriott, 2000).

Since germinated finger millet, germinated kidney beans and peanuts are basic ingredients promoted in preparation of complementary foods in Tanzania, it was the aim of this study to ascertain the levels of cyanide to avoid the risk of toxicity to the infants.

\section{Materials and methods}

Laboratory germinated and autoclaved samples Three batches of brown finger millet (Eleusine corocana L. Gaertner) and brown speckled kidney bean seeds (Phaseolus vulgaries var. Rose Coco) from 2007 harvest, were purchased in August, October and December from farmers in Ilonga, Kilosa District in central Tanzania. The materials were prepared and processed according to the methodology employed in our previous study (Mbithi et al., 2002), with very minor modifications. The samples were sorted by removing extraneous material and washed with distilled water, spread on trays and allowed to dry at $37^{\circ} \mathrm{C}$ for 24 hours. About $200 \mathrm{~g}$ each of finger millet and kidney bean samples were soaked for 3 hours and 8 hours in distilled water $(1: 2 \mathrm{w} / \mathrm{v}$, grains to water), respectively. The samples were then put in large petri-dishes, which were covered on top with perforated aluminium foil. Germination was followed for 48 hours at $30^{\circ} \mathrm{C}$ in the dark. After germination the grains were placed in autoclavable bags and autoclaved for $20 \mathrm{~min}$. at $121^{\circ} \mathrm{C}$. Raw, germinated and autoclaved grains were sampled out for cyanide determination. The purchased ingredients in both batches were aimed at preparing a complementary food for infants
Peanuts (Arachis hypogea) and mangoes (Mangifera indica, variety Kent) were purchased from farmers and the local market respectively, in the same village. The peanuts were winnowed and the broken nuts discarded. The seeds were roasted in oven at $150^{\circ} \mathrm{C}$ for $20 \mathrm{~min}$ with occasional turning. The mangoes were washed in clean water, peeled and cut into slices. The slices were blended by kitchen blender (Moulinex Blender, France) and the fibre screened out by a sieve to obtain puree. The remaining puree was dried in an oven at $60^{\circ} \mathrm{C}$ for $6 \mathrm{~h}$.

\section{Field germinated and autoclaved samples and samples of complementary food}

Similarly, a larger portion of finger millet (Eleusine coracana) and kidney beans from the same harvest was treated as described in the preceding section. About $20 \mathrm{~kg}$ of grains were soaked, $3 \mathrm{~h}$ for finger millet and $8 \mathrm{~h}$ for kidney beans in clean water $(1: 2 \mathrm{w} / \mathrm{v}$, grains to water). Water was drained and seeds kept in a field made germinator operating at a temperature of $28 \pm 2{ }^{\circ} \mathrm{C}$ for $48 \mathrm{~h}$ in the dark with relative humidity of $86-88 \%$. At the end of this period, the germinated seeds were autoclaved for $20 \mathrm{~min}$. and transferred to a solar drier. The same treatment for peanuts and mangoes were carried-out in the field but the mango puree was dried in a solar drier for $12 \mathrm{~h}$.

A mixture containing $65.2 \%, 19.1 \%, 8.0 \%$ and $7.7 \%$ of the processed finger millet, kidney beans, peanuts and mango respectively, was milled into composite flour. The formulation mixture was based on the results from in vitro studies described earlier by Mbithi et al. (2002). A total of 12 complementary food batches were produced and therefore 12 samples of complementary food were sampled each month for cyanide analysis. The complementary food was produced in the field during implementation of a feeding trial. The trial was conducted in Kilosa district with an objective of ascertaining the efficacy of the food with regard to infant growth and iron status.

\section{Cyanide determination}

The AOAC quantitative titrimetric method No. 915.03 (AOAC, 1995), was followed. $20 \mathrm{~g}$ sample was weighed and transferred into a distillation flask, to which $100 \mathrm{ml}$ of distilled water was added. The sample was macerated at room temperature for 2 $\mathrm{h}$ followed by $100 \mathrm{ml}$ distilled water. Steam was passed through the sample from a steam generator. Distillation was carried out until $150 \mathrm{ml}$ of distillate 
were collected in $20 \mathrm{ml}$ of $0.01 \mathrm{~N} \mathrm{AgNO}_{3}$ acidified with $1 \mathrm{ml} \mathrm{HNO}_{3}$. The amount of cyanide in the samples was determined by back titration with $0.02 \mathrm{~N}$ KSCN (potassium ferrocynide) using ferric alum indicator to determine the residual $\mathrm{AgNO}_{3}$ remaining in the distillate.

Cyanide as ppm $\mathrm{HCN}=\left[(\mathrm{A}-\mathrm{B}) \times \mathrm{N} \times 5.4 \times 10^{4}\right] /$ [Sample weight $(\mathrm{g}) \times \%$ dry matter] sample

Where $\mathrm{A}=\mathrm{mL}$ of $0.02 \mathrm{~N} \mathrm{AgNO}_{3}$ for test

$\mathrm{B}=\mathrm{mL}$ of $0.02 \mathrm{~N} \mathrm{AgNO}_{3}$ for blank sample I ml $0.02 \mathrm{~N} \mathrm{AgNO}_{3}=0.54 \mathrm{mg} \mathrm{HCN}$

\section{Statistical analysis}

Unless otherwise stated, all experiments were in triplicate and the means and standard deviations reported. An analysis of variance of the results was done at $95 \%$ confidence interval ( $\mathrm{P} £ 0.05$ ) using Tukey's Honestly significant difference. The analysis was done using SPSS 9.0 for windows computer software.

Table 1: Cyanide content of raw, germinated, autoclaved finger millet and kidney beans in $\mathrm{mg} / \mathrm{kg}$ fresh weight

\begin{tabular}{l|l|l|l}
\hline \multirow{2}{*}{ Sample } & \multicolumn{2}{l}{ Category } & $\begin{array}{l}\text { Cyanide content (Mean } \pm \text { Sd) } \\
\text { Finger millet }\end{array}$ \\
\hline Raw & Batch 1 & $28.6 \pm 0.5^{\mathrm{b}}$ & $25.6 \pm 0.4^{\mathrm{b}}$ \\
& Batch 2 & $28.2 \pm 0.3^{\mathrm{b}}$ & $25.8 \pm 0.5^{\mathrm{b}}$ \\
& Batch 3 & $29.0 \pm 0.2^{\mathrm{b}}$ & $25.6 \pm 0.2^{\mathrm{b}}$ \\
& Field sample & $29.1 \pm 1.0^{\mathrm{b}}$ & $25.4 \pm 0.4^{\mathrm{b}}$ \\
& Batch 1 & $61.3 \pm 0.4^{\mathrm{c}}$ & $45.5 \pm 0.4^{\mathrm{c}}$ \\
& Batch 2 & $60.2 \pm 0.3^{\mathrm{c}}$ & $45.4 \pm 0.3^{\mathrm{c}}$ \\
Autoclaved & Batch 3 & $61.2 \pm 0.6^{\mathrm{c}}$ & $45.4 \pm 0.5^{\mathrm{c}}$ \\
& Field sample & $61.5 \pm 0.5^{\mathrm{c}}$ & $45.0 \pm 0.4^{\mathrm{c}}$ \\
& Batch 1 & $17.7 \pm 0.5^{\mathrm{a}}$ & $14.8 \pm 0.2^{\mathrm{a}}$ \\
& Batch 2 & $18.6 \pm 0.3^{\mathrm{a}}$ & $14.7 \pm 0.4^{\mathrm{a}}$ \\
& Batch 3 & $18.5 \pm 0.5^{\mathrm{a}}$ & $14.5 \pm 0.2^{\mathrm{a}}$ \\
& Field sample & $18.9 \pm 0.4^{\mathrm{a}}$ & $14.5 \pm 0.6^{\mathrm{a}}$ \\
\hline
\end{tabular}

The final product (complementary flour) showed even lower levels of cyanide with an average of $19.1 \mathrm{ppm}$ (Figure 1) for complementary food samples produced throughout the year. There were no significant differences in cyanide levels in all the

\section{Results}

All raw samples contained some cyanide, which increased significantly during germination and dropped significantly again after autoclaving. In finger millet the cyanide content increased more than two-fold (by factors ranging between 2.11 and 2.14) from raw to germination stage and fell down to between 61.8 and $65.9 \%$ of the original content in raw samples after autoclaving. Kidney beans equally followed the same trend increasing by between 1.76 and 1.77 fold during germination and falling down to between 56.6 and $57.8 \%$ the original raw content after autoclaving. The field germinated and autoclaved samples did not significantly differ with the laboratory samples similarly treated. Cyanide was not detected in either raw or roasted peanuts. Equally, cyanide was not detected in raw mango sample and puree in both laboratory and field samples.
12 batches of complementary food produced in the field. Values are means and one standard deviation of three replicates for finger millet and kidney beans. Values with the same superscript in the same column are not significantly different. 


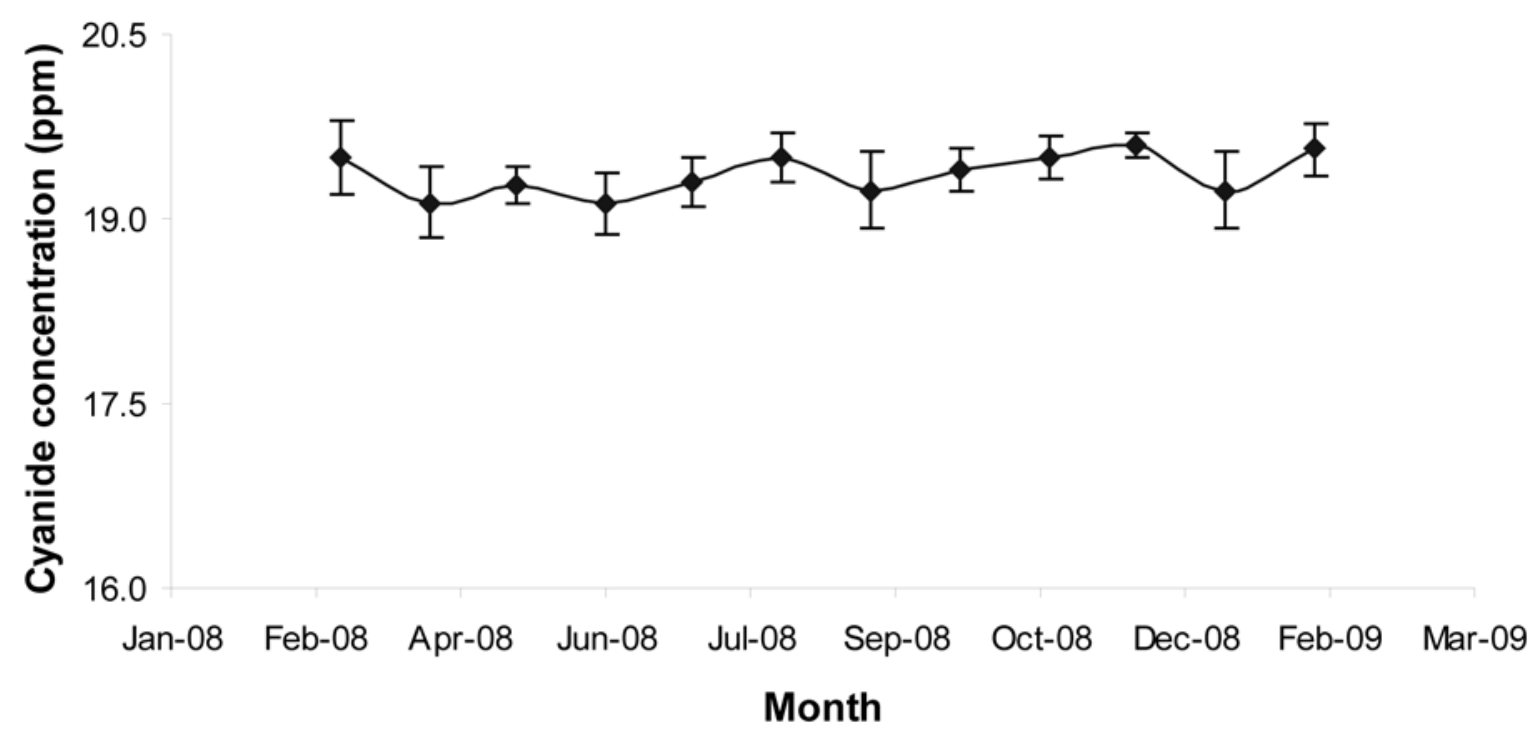

Figure 1: Cyanide concentration of complementary food produced every month

\section{Discussion}

Overall the results obtained indicate that the cyanide concentration in both finger millet and kidney beans is relatively low. Laswai (1992) investigating on the effect of germination of various varieties of sorghum millet found that germination significantly increased the mean hydrogen cyanide irrespective of variety. Relatively, the content of hydrogen cyanide in the un-germinated samples were quite low ranging between 11.7 to $14.7 \mathrm{ppm}$ as opposed to that of germinated samples 2 days at $23^{\circ} \mathrm{C}$, which was quite high ranging from 141.3 to $163.4 \mathrm{ppm}$. Surprisingly, Shayo et al. (1998) found cyanide content of 513.4 and $489.2 \mathrm{ppm}$ in finger millet malt from Moshi and Sumbawanga varieties. Regarding the kidney beans, similar results were found by Adeparusi (2001) who reported significant reduction on levels of cyanide in Lima beans (Phaseolus lunatus) after soaking autoclaving and toasting.

The average fatal dose of cyanide for an adult human is between 50 and $60 \mathrm{mg}$ per $100 \mathrm{~g}$ of dry matter (Panasiuk \& Bills, 1984; Aniche, 1990). EFSA (2004) and Salami (1994) quote values of $0.5-3.5 \mathrm{mg} / \mathrm{kg}$ body weight as lethal dose. The World Health Organisation (WHO, 2003) guidelines specify a figure of $0.05 \mathrm{mg} / \mathrm{kg}$ body weight/day. The amounts measured in the current research would indicate that the cyanide contents found in the millet and beans samples were well below the fatal limits but the frequency of ingestion and the small body weight of infants may still result into health risks.
Any procedure that reduces the cyanide content will thus be highly recommended in the preparation of complementary foods for infants.

Cooking does little to reduce this toxicity since most of the toxin occurs as glucoside (Drewnowski \& Gomez-Carneros, 2000). The fact that the samples were autoclaved at $121^{\circ} \mathrm{C}$ but still there remained detectable quantities of cyanide implies that some of the cyanogenic compounds exist in forms that are not readily volatile (Sopade, 2000). Previous studies reveal that the problem of production of cyanogenic glucoside dhurin from sorghum during germination is manageable. Firstly, the glucoside and the thurrin-synthesising enzyme are primarily located in the coleoptile, in a young shoot (Akazawa et al., 1960; Halkier \& Moller, 1989). The seed and root contain neither the glucoside nor the enzyme. Other workers have reported quite low levels in roots and seeds (Osuntongun et al., 1989). This implies that removal of the shoots after germination may help to minimize this problem.

Germination is a simple, cheap and easily adaptable technology. It is a very promising technique with regard to improving food intake in infants and children, once the risk of hydrocyanic acid toxicity in finger millet and kidney beans sprouts is eliminated or maintained to a minimum level. The risk is minimized by autoclaving which serves two purposes of partial cooking and safety. Glucosides in finger millet and kidney bean samples were significantly reduced with the autoclaving temperature employed in this study. However, 
ordinary cooking temperatures as previously reported by some workers seem not to have a significant effect on the reduction of the glucosides.

Received 17 February 2010

Revised 20 February 2010

Accepted 21 February 2010

\section{References}

Adeparusi, E.O. (2001) Effect of processing on the nutrients and anti-nutrients of lima bean (Phaseolus lunatus L.) flour. NahrungFood 45, 94 -96.

Ahmed, S., Mahgoub, S., \& Babiker, B. (1996) Changes in tannin and cyanides contents and diastatic activity during germination and the effect of traditional processing on cyanide content of sorghum cultivars, Food Chemistry 56, 159-162.

Akazawa, T., Miljanich, P. \& Conn, E.E. (1960) Studies of cyanogenic glucoside of sorghum vulgare. Plant physiology 35, 535-538.

Aniche, G.N. (1990) Studies on the effects of germination and drying conditions on the cyanide content of sorghum sprouts. Journal of Food Science and Technology, 27, 202-204.

AOAC (1995) Official Methods of Analysis. Association of Official Analytical Chemists methods, AOAC $16^{\text {th }}$ edition Nos. 963.13, 968.08, 970.12, 915.03, 920.87. Washington, D.C.

Drewnowski, A. \& Gomez-Carneros, C. (2000) Bitter taste, phytonutrients, and the consumer: A review article. American Journal of Clinical Nutrition 72, 14241435.

EFSA (2004) Opinion of the Scientific Panel on Food Additives, Flavourings, Processing Aids and Materials in Contact with Food (AFC) on Hydrocyanic Acid in Flavourings and other Food Ingredients with Flavouring Properties. Question no EFSA-Q-2003-0145. EFSA Journal 105.

Fennema, O.R. (1985) Food Chemistry. 2nd edition. Marcel Dekker, Inc. 270 Madison Avenue, New York. 991p.

Jones, D.A. (1998) Why are so many plants cyanogenic? Phytochemistry, 47, 155-162.

Laswai, H.S. (1992) The Role of Exogeneous and Endogenous Proteases in Processing of Sorghum. $\mathrm{PhD}$ thesis, University of Reading, p 266.
Leavesley, H.B., Li, L., Prabhakaran, K., Joseph L. Borowitz, J.L. \& Gary E. Isom, G.E. (2007) Interaction of cyanide and nitric oxide with cytochrome c oxidase: implications for acute cyanide toxicity. Toxicological Sciences 2008 101, 101-111.

Marriott, B.M. (2000) Functional foods: an ecologic perspective. American Journal of Clinical Nutrition 71, 1728S-1734S.

Mbithi-Mwikya, S., Van Camp, J., Mamiro, P., Ooghe, W., Kolsteren, P. \& Huyghebaert, A. (2002) Evaluation of nutritional characteristics of a finger millet based complementary food. Journal of Agricultural Food Chemistry, 50, 3030-3036.

Muzanila, Y. (1993) Effect of fermentation and storage upon levels of intermediate cyanide (cyanohydrins) in cassava flour. International Journal of Food Science and Nutrition 43, 199-203.

Onyeka, U. \& Dibia, I. (2002) Malted weaning food made from maize, soybean, groundnut and banana. Journal of the Science of Food and Agriculture 82, 513-516.

Panasiuk, O. \& Bills, D. (1984) Cyanide content of sorghum sprouts, Journal of Food Science 49, 791-793.

Salami, L.I. (1994) Cyanide content of two Nigerian local sprouted millet cultivars. International Journal of Food Science and Nutrition 45, $1-3$.

Shayo, N.B., Nnko, S.A.M., Gidamis, A.B. \& Dillon, V.M. (1998) Assessment of cyanogenic glucoside (cyanide) residues in Mbege: An opaque traditional Tanzanian beer. International Journal of Food Sciences and Nutrition 49, 333-338.

Shcneider, N. \& Anderson, B. (1986) G86-775 Prussic acid poisoning. Extension Historical Materials from University of NebraskaLincoln Extension. University of NebraskaLincoln.

Sopade, P.A. (2000) The fate of cyanogens during the cooking of cassava in тити, a traditional oven in Papua New Guinea. International Journal of Food Science and Technology 35, 173-182.

Traoré, T., Mouquet, C., Icard-Vernière, C., Traoré, A. \& Trèche, S. (2004) Changes in nutrient composition, phytate and cyanide contents and $Đ$-amylase activity during cereal malting in small production units in Ouagadougou (Burkina Faso). Food Chemistry 88, 105114. 
Uvere, P., Adenuga, O. \& Mordi, C. (2000) The effect of germination and kilning on the cyanogenic potential, amylase and alcohol levels in sorghum malts used for burukutu production. Journal of the Science of Food and Agriculture, 80, 352-358.

Wahed, M., Mahalanabis, D., Begum, M., Rahman, M. \& Islam, M. (1994) Energy-dense weaning foods liquefied by germinated wheat amylase: Effect on viscosity, osmolarity, macronutrients and bacterial growth. Food and Nutrition Bulletin 15, 257-261.

WHO (2003) Cyanide in drinking water. Background Document for development of WHO (World Health Organisation) Guidelines for drinking water quality. WHO/SDE/ WSH/03.04/05. 